DOI: http://dx.doi.org/10.1590/1678-457X.6356

\title{
Assessing environmental impacts using a comparative LCA of industrial and artisanal production processes: "Minas Cheese" case
}

\author{
Elbert Muller NIGRI ${ }^{1}$, Aline Capanema de BARROS ${ }^{1}$, Sonia Denise Ferreira ROCHA ${ }^{1}$, Eduardo Romeiro FILHO ${ }^{\text {* }}$
}

\begin{abstract}
This study uses the Life Cycle Assessment (LCA) methodology to evaluate and compare the environmental impacts caused by both the artisanal and the industrial manufacturing processes of "Minas cheese". This is a traditional cheese produced in the state of Minas Gerais (Brazil), and it is considered a "cultural patrimony" in the country. The high participation of artisanal producers in the market justifies this research, and this analysis can help the identification of opportunities to improve the environmental performance of several stages of the production system. The environmental impacts caused were also assessed and compared. The functional unit adopted was 1 kilogram $(\mathrm{Kg})$ of cheese. The system boundaries considered were the production process, conservation of product (before sale), and transport to consumer market. The milk production process was considered similar in both cases, and therefore it was not included in the assessment. The data were collected through interviews with the producers, observation, and a literature review; they were ordered and processed using the SimaPro 7 LCA software. According to the impact categories analyzed, the artisanal production exerted lower environmental impacts. This can be justified mainly because the industrial process includes the pasteurization stage, which uses dry wood as an energy source and refrigeration.
\end{abstract}

Keywords: LCA; Life Cycle Assessments; industrial production; artisanal process; "Minas" cheese; environmental impact.

\section{Introduction}

Minas cheese is a food product of significant economic importance to the Brazilian dairy industry (Nogueira et al. 2005). It started to be identified as a local symbol in the 18 th century, when its production using Portuguese techniques was developed. In 2008, the cheese was officially recognized as a cultural expression of Minas Gerais state by the "Instituto do PatrimônioHistórico e ArtísticoNacional” (Institute of Historical and Artistic Heritage) thus making it a Brazilian Intangible Patrimony (Programa Semeando, 2011). The manufacturing methods of the Minas cheese are distinct because they are based on artisanal practices and are deeply inserted in the history of the state. Nowadays, the cheese produced in Minas Gerais is very popular all over the country and, in order to attend the increasing demand, large scale production methods, such as the industrial processes, have been developed.

According to data released by the Associação Brasileira das Indústrias de Queijos - Brazilian Association of Manufacturers of Cheese (Abiq), in 2011, the country produced 867,000 tons of Minas cheese. This represented an increase in production by $9.4 \%$ when compared to that of 2010 (Associação Brasileira das Indústrias de Queijos, 2013). The artisanal Minas cheese, which is produced directly on the farm from raw milk, represents more than 29 thousand tons / year (Dores \& Ferreira, 2012). Considering the value of Minas cheese as a local culture identifier, its high production volume and its growing consumption, a comparative study on the environmental impacts of the artisanal and industrial production cycles is justified. In addition to this, consumers are increasingly aware of the sustainable characteristics of the products they purchase (Kim et al., 2013).
The main objective of this study was to assess the environmental impacts (per functional unit) caused by both artisanal and industrial manufacturing process of Minas cheese production. The LCA tool was also used to analyze and compare the results.

\subsection{Life Cycle Assessment}

One of the most recognized methods for assessing the environmental impacts associated to activities or products is the Life Cycle Assessment - LCA (Hospido et al., 2003). Its main potential in environmental decision-making process lies in providing a quantitative basis for assessing the potential improvements in environmental performance of a system throughout the life cycle. According to Azapagic \& Clift (1999), LCA has two main objectives as an environmental management tool. The first is to quantify and to evaluate the environmental performance of a product or a process from "cradle to grave" and thus to help the decision-makers to choose between alternative products and processes. Another objective of LCA is to provide a basis for assessing the potential improvements in the environmental performance of a product system.

Life cycle assessment (LCA) is a technique for assessing the potential environmental impacts associated with a product, process, or service throughout its lifetime (Kim et al., 2013; Siracusa et al., 2014). Chehebe (1998) highlights that life cycle assessment is a technique that allows a detailed evaluation of the environmental aspects and potential impacts associated with a product life cycle, ranging from the extraction and processing of the basic raw materials that enter the production to the final

${ }^{1}$ Production Engineering Department, Universidade Federal de Minas Gerais - UFMG, CEP 30161-010, Belo Horizonte, MG, Brasil, e-mail: romeiro@ufmg.br ${ }^{*}$ Corresponding author 
disposal of the product "from cradle to grave". This is done by identifying and quantifying energy and the materials used and the waste released into the environment (Consoli, 1993).

In order to make this evaluation, a systemic view of the process and the knowledge that an environmental load can be transferred from one stage to another are needed. This way, it is possible to identify the negative points of the life cycle and the possibility of avoiding them (Finkbeiner et al., 2006).

LCA also allows estimating the cumulative environmental impacts that result from all steps of the product's life cycle, which are not usually considered in more traditional analysis. A comprehensive overview of the environmental aspects of the product or process and a more accurate image of trade-offs in products and processes selection is provided (Environmental Protection Agency, 2006). In principle, LCA could be used as a decision support tool by three distinct groups (Cellura et al., 2012): Producers, to improve the environmental performance of a production system; Consumers, to guide purchasing decisions; and Policy-makers, to inform and direct long-term strategies. According to ISO standards 14040 and 14044 for LCA (International Organization for Standardization, 2006a, b), the method refers to the compilation and evaluation of the inputs, outputs, and the potential environmental impacts of a product scaled to a functional unit throughout its life cycle. Thereby, LCA is essentially a systematic assessment of the environmental impacts caused by products or services.

To understand the nature of the studies used to make recommendations in this paper, it is useful to understand what conducting an LCA entails (United Nations Environment Programme/Society of Environmental Toxicology and Chemistry, 2013). There are four phases defined by ISO that a practitioner should follow when conducting an LCA: Goal and scope definition, Life cycle inventory analysis, Life cycle impact assessment, and Interpretation. ISO 14040 (International Organization for Standardization, 2006a) divides Life Cycle Assessment into four stages: Goal and scope definition, Life cycle inventory, Life cycle impact assessment, and interpretation. Figure 1 shows a representation of these stages.

ISO standards have been redrafted and all required items have been collected into a single standard, ISO 14044 (International Organization for Standardization, 2006b). ISO

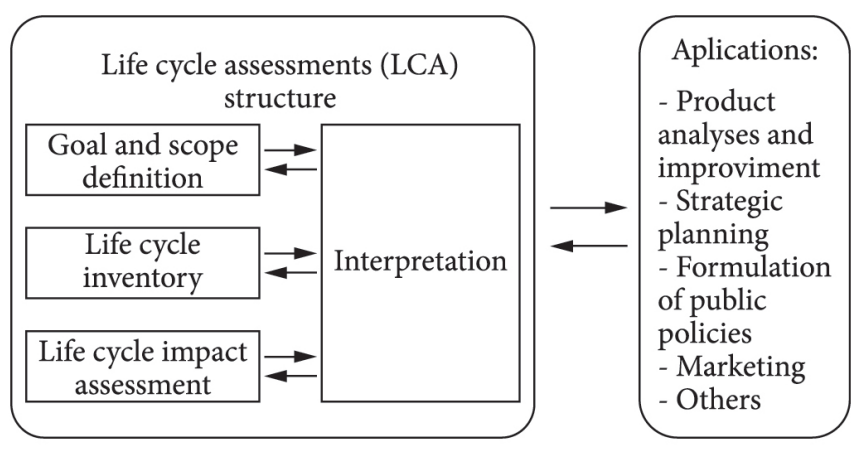

Figure 1. Adaptation of LCA's stages according to ISO 14040 (International Organization for Standardization, 2006a).
14040 (International Organization for Standardization, 2006a) was kept as a model document; however, all required items were transferred to the new standard (Finkbeiner et al., 2006). These standards provide an internationally accepted method of conducting LCA, These standards provide an internationally accepted LCA methodology adaptable to a variety of situations with different characteristics and levels of complexity. Therefore, it is possible to adapt the LCA approach to specific needs of each research (Kim et al., 2013).

The reformulated standards are (Figure 2):

- ISO 14040 - Environmental management: life cycle assessment-principles and framework. This standard defines the main terms of the process by describing and determining the general principles of goal and scope definition, inventory analysis, impact assessment, and interpretation. It describes the criteria for making reports and analyses. The way the stages are divided is not detailed and the method used is not specified (Ribeiro, 2009);

- ISO 14044 - Environmental management: life cycle assessment - requirements and guidelines. This standard presents the analysis phase of the life cycle inventory (LCI), during which the data for inputs such as energy costs and emissions during the life cycle of the product are collected. It also shows the impact assessment phase of life cycle (LCIA), in which the environmental impacts related to the object of study are characterized. It also includes the interpretation phase that presents the results based on a critical review of the study, comparing them to the objectives described at the beginning of the analysis (Hinz, 2007).

\subsection{Goal and scope definition}

In this stage, the LCA's objectives, the reasons of the study, the target public, and the intended use of the results must be clearly stated and so does the scope, which defines the basic parameters of LCA such as the functional unit, system boundaries, allocation rules, and data quality (Hospido et al., 2003).

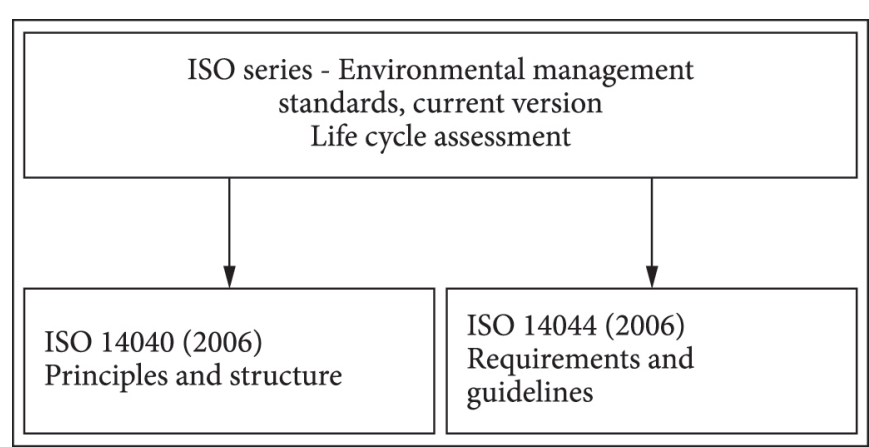

Figure 2. ISO standards current version. Source: adapted from Hinz (2007). 


\subsection{Life cycle inventory}

In a product's life cycle, the inventory is related to data collection, their classification, and grouping in predetermined categories. Values are assigned according to a previously defined importance scale so that the mass and energy balance are calculated (Valt, 2004). According to ISO 14041 (International Organization for Standardization, 1998), the analysis of Life Cycle Inventory (LCI) involves data collection and calculation procedures in order to allow quantifying the inputs: energy and raw materials and other physical inputs and outputs: atmospheric emissions, liquid effluents, solid waste, and other environmental aspects.

\subsection{Life cycle impact assessment}

The Life Cycle Impact Assessment (LCIA) models select environmental issues, called impact categories, and uses category indicators to condense and explain the results of the Life Cycle Inventory (LCI). Category indicators are used to reflect the aggregated emissions or resources use of each impact category. These category indicators represent the "potential environmental impacts" (Hinz, 2007). According to Chehebe (1998), the LCIA is a qualitative / quantitative process that allows the understanding and assessing of the magnitude and significance of environmental impacts based on the results obtained from the analysis of the inventory.

\subsection{Interpretation}

The ultimate goal of this phase is to draw conclusions and make recommendations reflecting on the identification of significant issues of the product or activity being assessed (Finkbeiner et al., 2006). According to the ISO 14043 (International Organization for Standardization, 2000), this phase defines a systematic procedure to identify, qualify, check, and evaluate the results of the life cycle inventory or the life cycle impact assessment, facilitating the interpretation of the life cycle and the creation of a data base from which conclusions and recommendations will be embodied and used on the Final Report.

\section{Materials and methods}

The methodology adopted in this research basically followed the following steps: First, the production process of Minas Cheese was described. The second step consisted of data collection and refinement. To collect field data, an industrial producer and an artisan producer of Minas cheese were selected. The amount and type of inputs used in production as well as transport and origin of key inputs were obtained through interviews with these producers using a script with predetermined questions. The data were collected in two cities in the countryside of the state of Minas Gerais: Serro and Entre Rios de Minas. They were measured according to the amount of product produced and then calculated to fit the functional unit adopted. The electricity consumption was obtained from the power of each device used in the process and its running time. The amount of wood used in the industrial production process of Minas cheese was expressed in cubic meters. Emissions of gases and particulates related to the burning of firewood were obtained from the literature, except for the CO2, which was calculated. The wood used in the process came from the property that produces industrial cheese, and the environmental impact during its production was not allocated to the system.

The data related to the environmental impacts from the production of inputs used in the production of Minas cheese (except for the firewood) were acquired from the Ecoinvent database that includes the SimaPro7 software. Table 1 shows the source of the data used by the software. The use of yeast and rennet was not included in the analysis due to the impossibility to measure their environmental impacts and the fact that they are not included in the software library. Regarding the transport of raw materials and final product, the distances were calculated and the type of transport, including the model, was recorded.

Table 1. Source of the data used in the research.

\begin{tabular}{|c|c|}
\hline Data & Source \\
\hline Nitric acid & Nitric acid, $\mathbf{5 0} \%$ in $\mathbf{H}_{2} \mathbf{O}$, at plant/RER S -Life cycle inventories of chemicals (Althaus et al., 2007). \\
\hline Calcium Chloride & Calcium chloride, $\mathbf{C a C l}_{2}$, at plant/RER S - Life cycle inventories of chemicals (Althaus et al., 2007). \\
\hline Chlorine & Chlorine, liquid, production mix, at plant/RER S - Life cycle inventories of chemicals (Althaus et al., 2007). \\
\hline Detergent & Alkylbenzenesulfonate, linear, petrochemical, at plant/RER U -Life Cycle Inventories of Detergents (Zah \& Hischier, 2007). \\
\hline Diesel & $\begin{array}{l}\text { Diesel, at refinery/1/US- Data Details for Petroleum Refining (Franklin Associates, 2003). } \\
\mathbf{1}^{\mathbf{0}} \text { Inventário Nacional de Emissões Atmosféricas por Veículos Automotores Rodoviários. (Brasil, 2010). }\end{array}$ \\
\hline Electricity & Electricity, low voltage, production BR, at grid/BR U - Strommix und Stromnetz (Frischknecht et al., 2007). \\
\hline Gasoline & $\begin{array}{l}\text { Gasoline, at refinery/1/US - Data Details for Petroleum Refining (Franklin Associates, 2003). } \\
\mathbf{1}^{\circ} \text { Inventário Nacional de Emissões Atmosféricas por Veículos Automotores Rodoviários. (Brasil, 2010). }\end{array}$ \\
\hline Milk & LCA food data base. (Nielsen et al., 2003). \\
\hline Plástic (polystyrene) & $\begin{array}{l}\text { Polystyrene (general purpose) granulate (GPPS), prod. mix,RER - ELCD database } 2.0 \text { (European Platform on Life Cycle } \\
\text { Assessment, 2002). }\end{array}$ \\
\hline Paperboard & $\begin{array}{l}\text { Packaging, corrugated board, mixed fibre, single wall, at plant/RER U - Life Cycle Inventories of Packaging and Graphical } \\
\text { Paper (Hischier, 2007). }\end{array}$ \\
\hline Salt & Sodium chlorate, powder, at plant/RER S - Life Cycle Inventories of Chemicals (Althaus et al., 2007). \\
\hline Caustic Soda & Sodium hydroxide, $\mathbf{5 0} \%$ in $\mathbf{H 2 O}$, diaphragm cell, at plant/RERS - Life Cycle Inventories of Chemicals (Althaus et al., 2007). \\
\hline Wastewater & $\begin{array}{l}\text { Caracterização de efluentes gerados em laticícios - Controle Ambiental em Pequenas e Médias Indústrias de Laticínios } \\
\text { (Machado et al., 2002). }\end{array}$ \\
\hline
\end{tabular}


The environmental impacts were calculated using the software. The established limit involves various stages from the beginning to the end of the process, including the transportation of raw materials and the delivery of the final product in a specific sales establishment. The greatest impact of the transport involves the transportation of the final product $(310 \mathrm{~km})$, which is much higher when compared to the transport of milk, the main input $(5 \mathrm{~km})$. Following that, the value of the functional unit was determined. The life-cycle of machinery used in the processing of products was considered. Subsequently, the data collected were entered in the software for analysis. After determining the environmental aspects and impacts, a comparative analysis of the products between the industrial and artisanal manufacturing processes was carried out. The categories of environmental impacts evaluated by the eco-indicator 99 used by SimaPro were: carcinogens, breathing inorganic particles, organic particles breathing, climate change, radiation, depletion of the ozone layer, ecotoxicity, acidification/eutrophication, and land and mineral use.

This study is based on the Eco-indicator 99; the method of assessing the impacts caused by the products life cycle used in this procedure was mainly applied in the weighing stage of the LCA. It differs from the other methods because it focuses on the damages caused by products or activities, instead of focusing only on the various impact categories (Pre Consultants, 2000).

\section{Results and discussion}

\subsection{Description of the manufacturing process of artisanal and industrial cheese}

The production of artisanal cheese begins by pouring milk into a container containing a certain amount of yeast typical from Serro, called "pingo" (this process was also described by Machado et al., 2004). The rennet is then added to the mixture, which causes the coagulation of milk proteins (solid portion of the milk) that is separated from the whey. This step takes about 45 to 60 minutes. The solid portion is completely separated from the liquid by sedimentation. The solids are removed from the container using a sieve and put into molds, in which they are pressed and turned at the same time. Salt is then added on the upper side, and after approximately five hours the cheese is turned again and more salt is added to the other side (the time for the addition of salt can vary between different producers and conditions, as described by Hofmeister et al., 2005). After fourteen hours, the cheese is removed from the mold and placed on shelves so that the ripening process starts. The rest of the whey mixed with salt that runs off during the salting stage is collected and used in the next cycle of cheese production (the "pingo"). After maturing on the farm for four days, the cheese is taken to a cooperative, weighed, and washed. It still takes five more days for the cheese to finish maturing in cold storage.

Finally, it is packaged and transported to retailers. The phase of the cheese manufacturing process that takes place on the farm does not require electricity because refrigeration is not necessary in the process. The industrial production of Minas cheese also begins with the milk; however, milk is taken to the cooperative immediately after milking. It is then standardized with around 3 to $3.2 \%$ of fat and pasteurized at $75^{\circ} \mathrm{C}$ for 15 seconds. Calcium chloride is added in order to replace the calcium lost during pasteurization, and the yeast is added, which in this case it is industrialized. The milk is poured into a tank, to which the rennet is added in order to coagulate the solid portion of the milk from the whey. After complete separation, the solid portion is cut and decanted. It is pressed inside the tank, cut in cubes, and molded. The cheese is pressed in circular molds with a membrane placed between the cheese mass and the mold for about twenty minutes. It is then turned upside down and pressed again for twenty more minutes. The membrane is removed, and the cheese is pressed again for ten more minutes. Following that, the cheese is refrigerated for about one day. Only then, is the mold is removed and the cheese in placed into a brine, in which it stays for about six hours.. It takes two days for the cheese to dry after this process, during which it is turned upside down three times for full maturity of the cheese. Finally, after the ripening stage that takes ten more days, the cheese is packaged and prepared to be transported. This study considered that the distance between the manufacturing place and the retailer for both processes (industrial and artisanal) was of $310 \mathrm{~km}$.

The main difference between the two cheese making processes is that the artisanal process uses raw milk. It also does not need to use energy, different from the industrial process, which needs thermal energy generated by the dry wood for pasteurization and electricity for the refrigeration of the cheese. It is only from the moment when the artisanal cheese is delivered to the cooperative, after maturing for four days, that both processes become similar since the cooperative is responsible for labeling both cheeses. Figure 3 represents both processes. The functional unit adopted was $1 \mathrm{~kg}$ of Minas cheese, which is the unit of cheese commonly commercialized. Figure 2 also shows the production of both artisanal and industrial productions of Minas cheese, together with the amount of inputs according to the functional unit.

There are some differences between the use of inputs, such as raw materials and energy, in the artisanal and the industrial manufacturing of this kind of cheese. Calcium chloride is not used in the artisanal process because the milk is not pasteurized, and thus does it not loose calcium. The artisanal producer also does not use industrialized yeast once the yeast is made during the production of the cheese, as described before. When it comes to the rennet, the artisanal producer uses a much larger amount than that used in the industrial process. Both processes use about the same amount of water and, compared to the amount of water used in Norway, it varies from 22.0 to 33.4 liter for 1 kilogram of cheese, according to Maganha (2006), which is a relatively higher value. Therefore, it can be concluded that the energy consumption is much higher in the industrial process. This happens because the only time when the artisanal producer needs energy is when the water is pumped from the well. The electrical energy required was measured for every equipment used during the manufacturing process. Electricity is mostly used in the refrigeration chambers and by the pumps used to transport the milk inside the plant; the electricity used for lighting was also estimated. Dry wood is only used in the industrial process as a fuel for the boiler that is used to generate steam to heat and move the milk. Both processes need fuel 


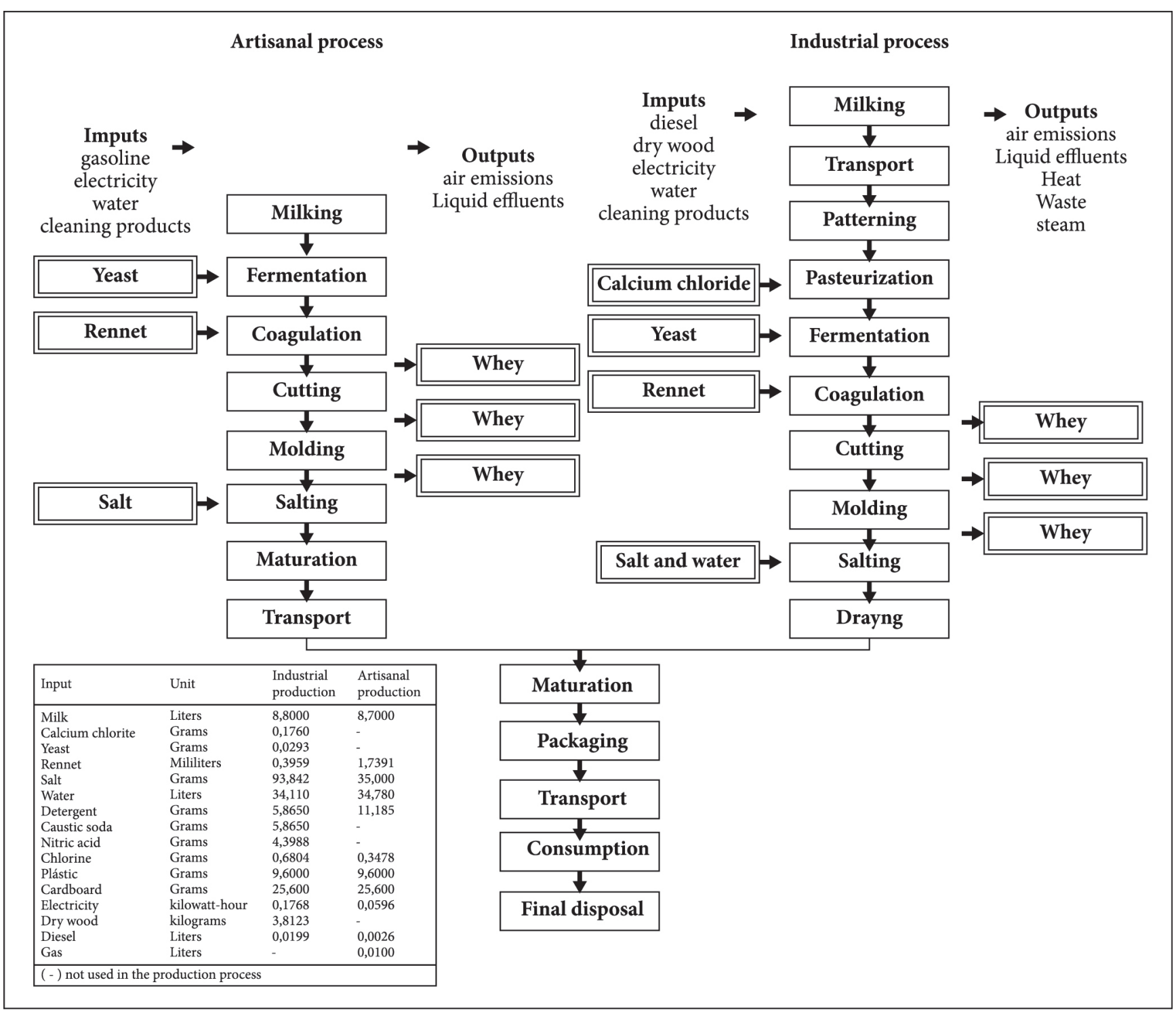

Figure 3. Stages of artisanal and industrial manufacturing processes of Minas cheese.

for transportation. The industrial process uses slightly more fuel than that of the artisanal since the milk is transported by trucks from the farm to the cooperative, whereas the artisanal producer delivers the final product to the cooperative using smaller gasoline powered vehicles. During the distribution to retailers, both processes use the same diesel-powered truck.

\subsection{Environmental impacts caused by the manufacturing of Minas cheese}

The data regarding the environmental impacts of the production of Minas cheese were obtained with the LCA software Simapro, using the Eco-indicator 99 method (Table 2). This method generates results in dimensionless numbers, expressed in PT - mili-points (Pre Consultants, 2000). Nevertheless, their absolute values are not the most important result in this case because the main objective of this study is a comparison between the environmental impacts of artisanal and industrial processes.
For a better comparison and visualization, the data fed to the software were divided into the following stages: Transportation of the milk to the cheese factory, pumping, refrigeration, heating of the boiler, lighting, Packaging, Transportation of the cheese to the retailer, and cleaning. The milk, salt, and sodium chloride were entered as material in the life cycle. The cleaning stage includes the emission of liquid effluents generated by the production and use of chlorine, detergent, caustic soda, and nitric acid.

\subsection{Environmental impacts caused by the industrial and artisanal processes of cheese manufacturing}

Figure $4 \mathrm{~A}$ shows the potential environmental impacts caused during the Minas cheese industrial production. It can be seen that milk production is the most responsible for the environmental impacts, followed by heating and refrigeration. Milk production exerts a significant impact mainly because of land use, while heating is harmful to the environment due to the dry wood used as fuel. Finally, the impacts created by the 
Table 2. Results obtained from the use of Eco-indicator 99.

\begin{tabular}{|c|c|c|c|c|c|c|c|c|}
\hline $\begin{array}{l}\text { Industrial cheese } \\
\text { Impact category } \\
\text { Unit (PT) }\end{array}$ & heating & pumping & Packaging & lighting & cleaning & refrigeration & $\begin{array}{l}\text { Transport } \\
\text { milk }\end{array}$ & $\begin{array}{c}\text { Transport } \\
\text { cheese }\end{array}$ \\
\hline Total & 0.476 & 0.0433 & 0.00613 & 0.0448 & 0.00249 & 0.191 & 0.00323 & 0.000477 \\
\hline Respiratory organics & $1.05 \mathrm{E}-5$ & $1.08 \mathrm{E}-7$ & $2.1 \mathrm{E}-6$ & $1.12 \mathrm{E}-7$ & $5.28 \mathrm{E}-7$ & $4.75 \mathrm{E}-7$ & $1.52 \mathrm{E}-5$ & $2.25 \mathrm{E}-6$ \\
\hline Respiratory inorganics & 0.436 & $5.15 \mathrm{E}-5$ & 0.000959 & $5.33 \mathrm{E}-5$ & 0.000511 & 0.000227 & 0.000489 & $7.18 \mathrm{E}-5$ \\
\hline Ozone layer & 0 & $1.01 \mathrm{E}-8$ & $9.61 \mathrm{E}-8$ & $1.05 \mathrm{E}-8$ & $1.17 \mathrm{E}-7$ & $4.45 \mathrm{E}-8$ & 7.1E-11 & $1.05 \mathrm{E}-11$ \\
\hline Ecotoxicity & 0 & $3.19 \mathrm{E}-5$ & 0.000105 & $3.31 \mathrm{E}-5$ & $7.58 \mathrm{E}-5$ & 0.000141 & $4.01 \mathrm{E}-6$ & $5.92 \mathrm{E}-7$ \\
\hline $\begin{array}{l}\text { Acidifacation/ } \\
\text { eutrophication }\end{array}$ & 0.00353 & $3.31 \mathrm{E}-6$ & $8.03 \mathrm{E}-5$ & $3.43 \mathrm{E}-6$ & $5.27 \mathrm{E}-5$ & $1.46 \mathrm{E}-5$ & $3.86 \mathrm{E}-5$ & $5.69 \mathrm{E}-6$ \\
\hline Land use & 0 & $3.61 \mathrm{E}-5$ & 0.000882 & $3.74 \mathrm{E}-5$ & $1.59 \mathrm{E}-5$ & 0.000159 & 0 & 0 \\
\hline Respiratory inorganics & 0 & $3.65 \mathrm{E}-8$ & $2.1 \mathrm{E}-6$ & $2.16 \mathrm{E}-8$ & $7.55 \mathrm{E}-7$ & $1.88 \mathrm{E}-7$ & $1.12 \mathrm{E}-6$ & $2.25 \mathrm{E}-6$ \\
\hline Climate change & 0 & $1.74 \mathrm{E}-5$ & 0.000959 & $1.03 \mathrm{E}-5$ & 0.000423 & $8.97 \mathrm{E}-5$ & 0.000185 & $7.18 \mathrm{E}-5$ \\
\hline Radiation & 0 & $1.78 \mathrm{E}-5$ & 0.000437 & $1.05 \mathrm{E}-5$ & 0.000131 & $9.18 \mathrm{E}-5$ & 0.000191 & $5.71 \mathrm{E}-5$ \\
\hline Ozone layer & 0 & $2.01 \mathrm{E}-7$ & $3.86 \mathrm{E}-6$ & $1.66 \mathrm{E}-7$ & $1.93 \mathrm{E}-6$ & $1.45 \mathrm{E}-6$ & 0 & 0 \\
\hline Ecotoxicity & 0 & $3.42 \mathrm{E}-9$ & $9.61 \mathrm{E}-8$ & $2.02 \mathrm{E}-9$ & $7.19 \mathrm{E}-8$ & $1.76 \mathrm{E}-8$ & $3.66 \mathrm{E}-11$ & $1.05 \mathrm{E}-11$ \\
\hline $\begin{array}{l}\text { Acidifacation/ } \\
\text { eutrophication }\end{array}$ & 0 & $1.08 \mathrm{E}-5$ & 0.000105 & $6.39 \mathrm{E}-6$ & $6.26 \mathrm{E}-5$ & $5.57 \mathrm{E}-5$ & $2.07 \mathrm{E}-6$ & $5.92 \mathrm{E}-7$ \\
\hline Land use & 0 & $1.12 \mathrm{E}-6$ & $8.03 \mathrm{E}-5$ & $6.61 \mathrm{E}-7$ & $2.93 \mathrm{E}-5$ & $5.76 \mathrm{E}-6$ & $1.88 \mathrm{E}-5$ & $5.69 \mathrm{E}-6$ \\
\hline Minerals & 0 & $1.22 \mathrm{E}-5$ & 0.000882 & $7.21 \mathrm{E}-6$ & $1.24 \mathrm{E}-5$ & $6.29 \mathrm{E}-5$ & 0 & 0 \\
\hline Fossil fuels & 0 & $6.17 \mathrm{E}-6$ & $4.08 \mathrm{E}-5$ & $3.65 \mathrm{E}-6$ & $4.04 \mathrm{E}-5$ & $3.18 \mathrm{E}-5$ & 0 & 0 \\
\hline
\end{tabular}

refrigeration stage are mostly due to the amount of electricity it requires. Although it was considered that all final product was transported over a distance of $310 \mathrm{~km}$, the environmental impact related to the transportation of the cheese was insignificant when compared to that of the others. The cleaning stage, packaging, and the use of calcium chloride do not exert significant impacts either.

During the artisanal process of cheese manufacturing, there is no need for heating, thus it is not necessary to burn dry wood. It is also worth saying that there is virtually no use of electricity, which is only used to pump the water from the well and electricity. The product is refrigerated only after being packaged. Figure 4B shows the milk production as the main cause of environmental impact in cheese production. The impact, however, is similar in both processes, the industrial and artisanal. Transportation, cleaning, packaging, pumping, and use of salt and lighting do not create significant impacts during the artisanal process of cheese production. Refrigeration, besides the milk production, is the only factor to exert significant impacts.

The environmental impacts of the industrial manufacturing of Minas cheese are shown in Figure 5A. The main impacts are the inhaling of inorganic particles caused mostly by the heating of the boiler and milk production, followed by land use, also a consequence of milk production, and the generation of carcinogens due to the use of electricity, mainly during the refrigeration stage. The depletion of the ozone layer, radioactive substances, inhaling of organic particles, and minerals did not show significant results.

The main environmental impacts of the artisanal process are almost entirely the result of milk production. They are: land use for livestock, inhaling of inorganic particles, and use of fossil fuels (Figure 5B). The refrigeration stage is the main cause of carcinogenicity. Impacts such as inhaling of organic particles, depletion of ozone layer, radiation, ecotoxicity, and minerals were not significant.

\subsection{Comparison between the environmental impacts of the artisanal and industrial processes of minas cheese production}

The graph shown in Figure 6A compares the percentage of the impacts of the industrial and artisanal processes of Minas cheese production. Figure $6 \mathrm{~B}$ shows the general impacts of each method. It is possible to see that the environmental impact of the industrial production process of Minas cheese is greater than that of the artisanal production process in all impact categories considered by the method. 


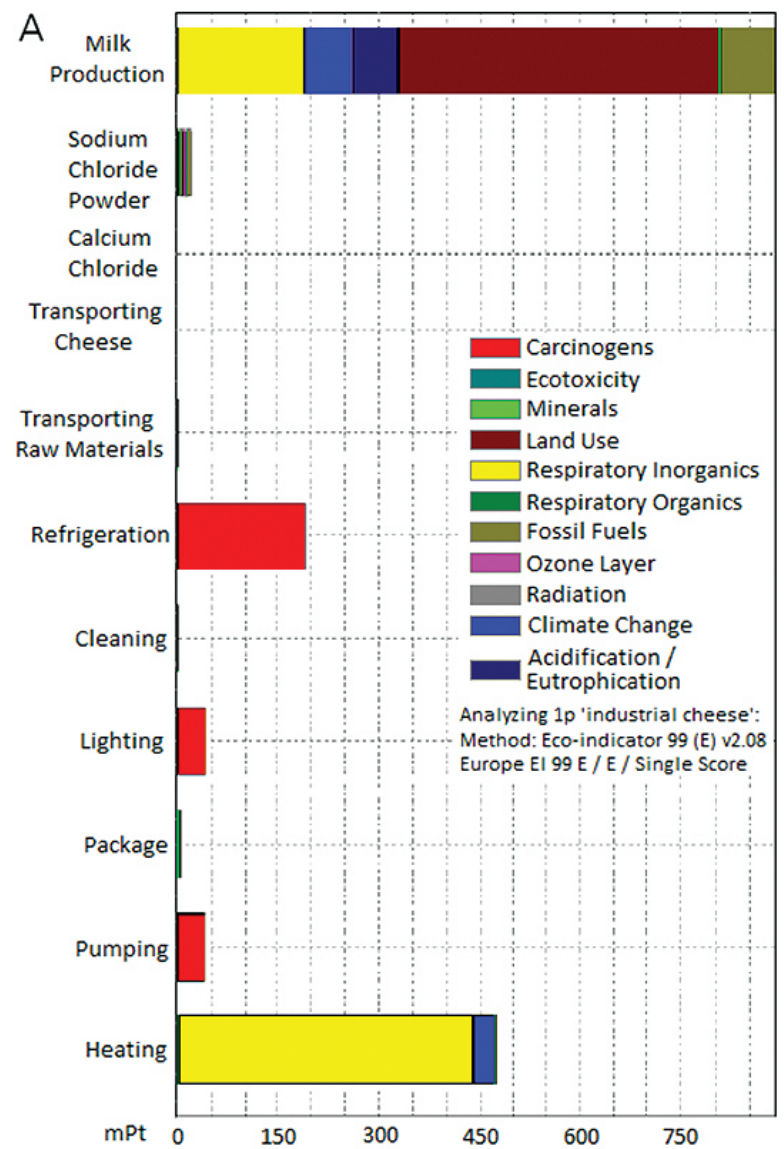

B

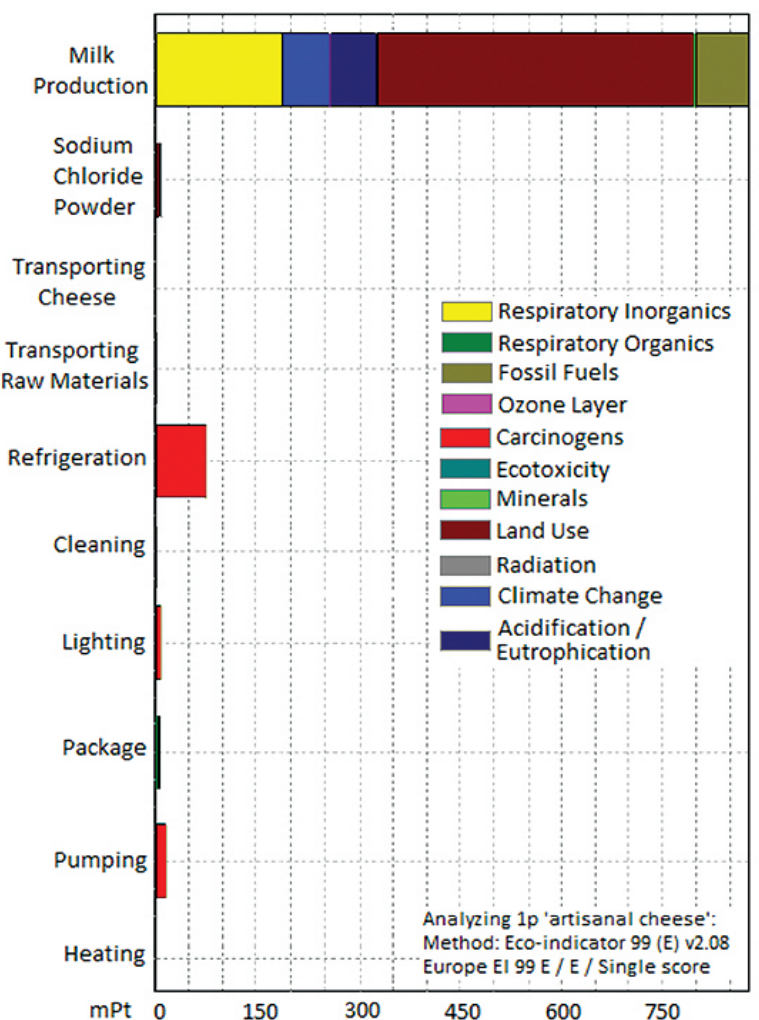

Figure 4. Potential causes of environmental impacts in the industrial (A) and artisanal (B) minas cheese manufacturing processes.
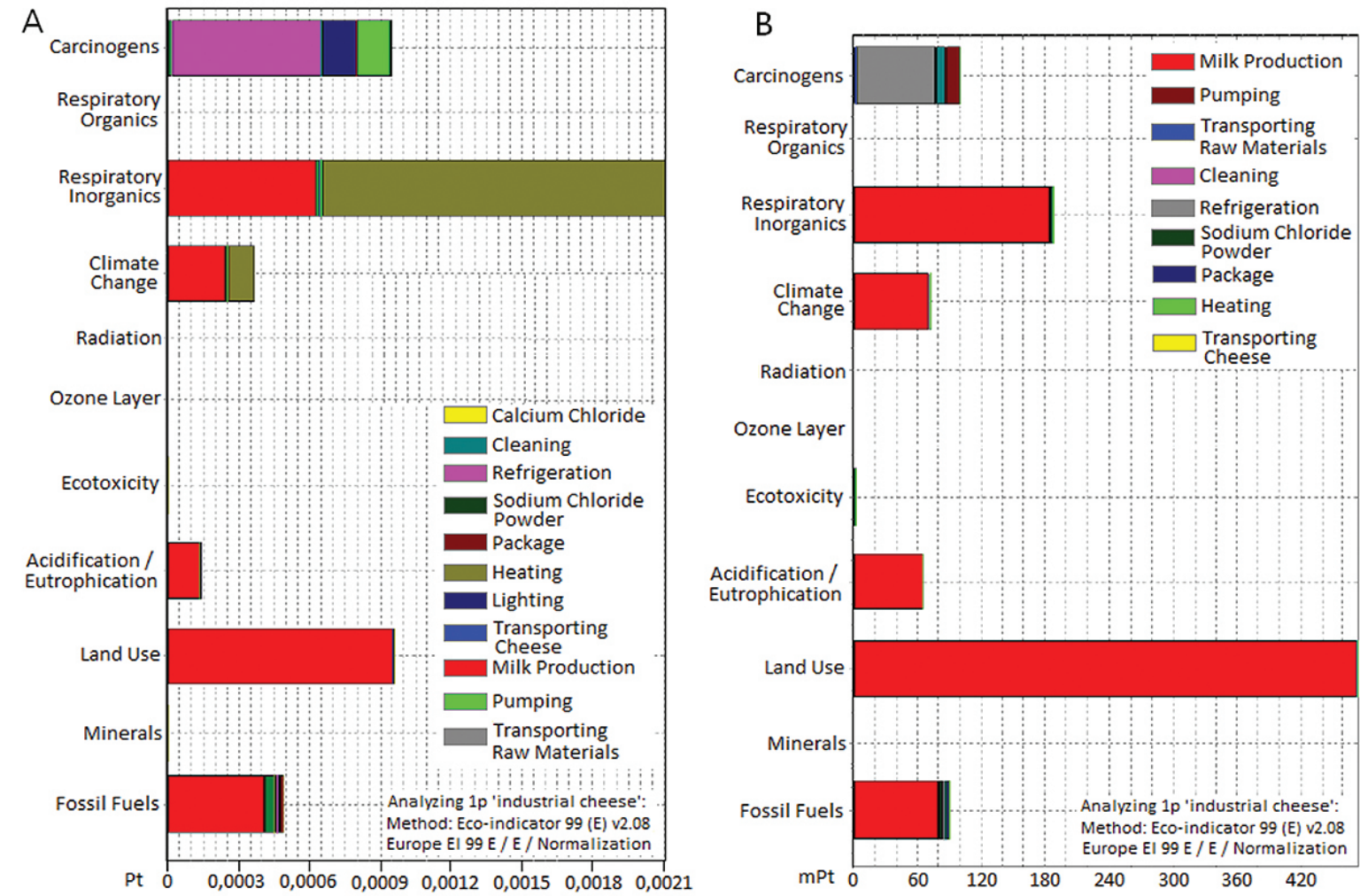

Figure 5. Environmental impacts of the (A) industrial and (B) artisanal manufacturing of Minas cheese. 


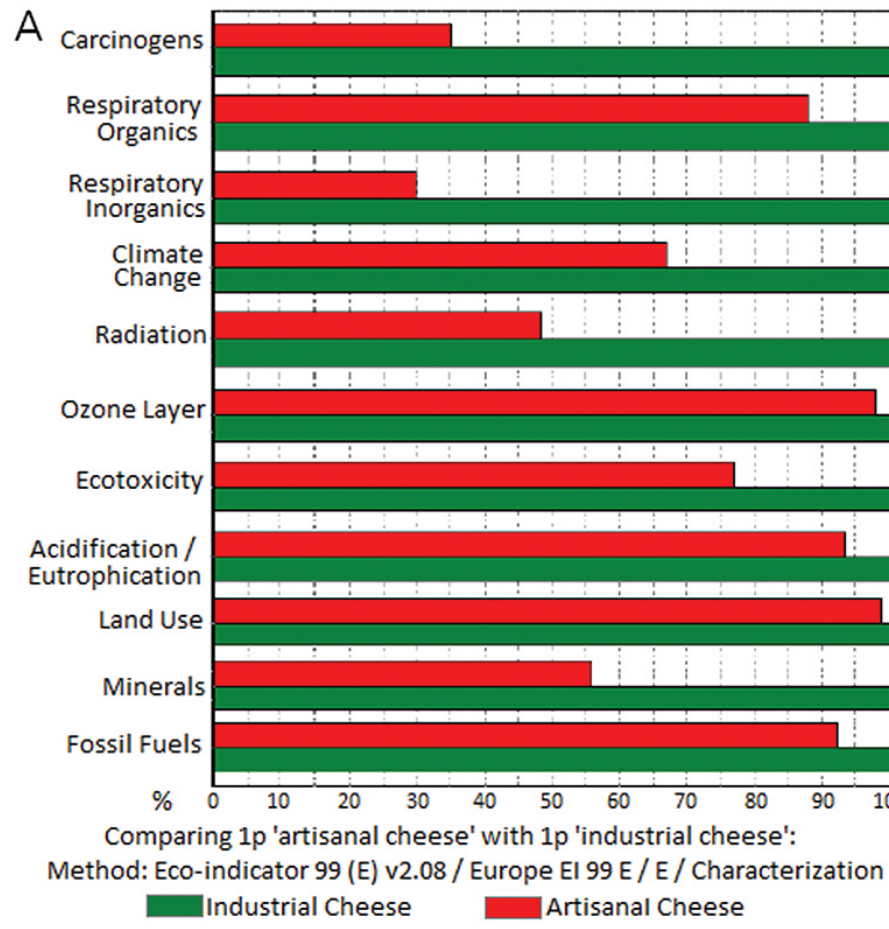

Figure 6. Comparison between the impacts of each production method.

\section{Conclusion}

When all the cheese production stages were analyzed and compared, it was found that the milk production stage is the one that exerts the greater environmental impacts. This result is consistent with the studies of Berlin (2002) and Kim et al. (2013).

It was also demonstrated that the complete industrial process of Minas cheese production has more impacts than those of the artisanal process. This is justified mainly because the industrial process includes the pasteurization stages, which use dry wood, as energy source, and refrigeration.

However, the fact that the artisanal producers do not use pasteurized milk in their cheese production is seen as a negative aspect since there is a risk of milk contamination. Another downside of the artisanal manufacturing process is the low production rate that cannot meet the increasing market demand for this cheese.

Regarding the liquid effluents, the use of whey for animal feeding drastically reduces the impacts exerted by both production processes. The use of water treatment plant by the industrial producer and the use of pits by the artisanal process also contribute to the reduction of environmental impacts. It is important to stress that the characteristics of the effluents generated are very specific and show great variability, even for the same producer. Nevertheless, it is still possible to say that the amount of liquid effluents generated by the artisanal cheese production is lower than that of the industrial process since it includes less stages than those of the industrial process.

Having small producers of artisanal cheese that are geographically well distributed and who produce for local

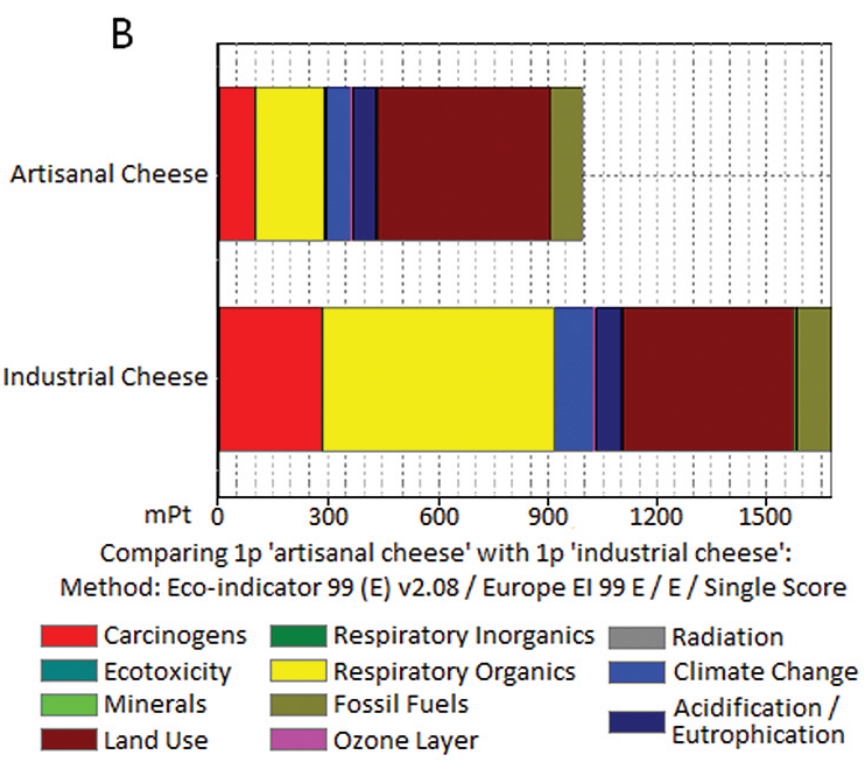

B

markets (i.e. a small village or city) could be an environmental alternative to the big dairy factories that otherwise have to travel long distances to deliver cheese products. This would reduce not only the impacts of the industrial cheese production but also those involved in the transportation of the cheese to these regions. However, there would be a greater need for strict inspection due to the use of raw milk, which is more likely to be contaminated than the pasteurized milk during cheese production.

The main objective of this research was to compare the environmental impacts of two different processes of minas cheese production. The results demonstrated that the traditional (artisanal) process has less impact, especially in terms of energy consumption. These results encourage the development of new technologies (e.g. new equipment and machines) to be adapted to the traditional processes. However, some points remain unclear, indicating the need for future studies. Firstly, the analysis of the impact of different production scales on the environment. This initial observation leads to a hypothesis that a geographically distributed production (in different small diary companies) could reduce the environmental impacts if the producers adopted some "good practices" related to residues and effluents. Nevertheless, this research did not demonstrate it quantitatively, and this aspect was not included in the literature review. A further LCA study on different functional units, analyzing the impacts of the increase of artisanal cheese production is recommended. Finally, another study could focus on the development of a specific diary machinery for small diary producers. 


\section{References}

Althaus, H. J., Chudacoff, M., Hischier, R., Jungbluth, N., Osses, M., \& Primas, A. (2007). Life cycle inventories of chemicals: data v2.0. Dübendorf: Swiss Centre for Life Cycle Inventories. Ecoinvent Report No. 8. Retrieved from http: www.ecoinvent.org

Associação Brasileira das Indústrias de Queijos - ABIQ. (2013). Mercado de queijos no Brasil. São Paulo. Retrieved from http://www. abiq.com.br/default.asp

Azapagic, A., \& Clift, R. (1999). Life cycle assessment and multiobjectiveoptimisation. Journal of Cleaner Production, 7(2), 135-143. http://dx.doi.org/10.1016/S0959-6526(98)00051-1

Berlin, J. 2002. Environmental life cycle assessment (LCA) of semihard cheese. International Dairy Journal, 12(11), 939-953. http://dx.doi. org/10.1016/S0958-6946(02)00112-7

Brasil, Ministério do Meio Ambiente, Secretaria de Mudanças Climáticas e Qualidade Ambiental. (2010). $1^{\circ}$ inventário nacional de emissões atmosféricas por veículos automotores rodoviários. Brasília. Retrieved from http://www.cntdespoluir.org.br/Downloads/ Inventario_22_03.pdf

Cellura, M., Ardente, F., \& Long, S. (2012). From the LCA of food products to the environmental assessment of protected crops districts: a case-study in the south of Italy. Journal of Environmental Management, 93(1), 194-208. PMid:22054586. http://dx.doi. org/10.1016/j.jenvman.2011.08.019

Chehebe, J. R. B. (1998). Análise do ciclo de vida de produtos. Rio de Janeiro: Qualitymark.

Consoli, F. (1993). Guidelines for life-cycle assessment: a "code of practice”. Brussels: SETAC.

Dores, T. M., \& Ferreira, C. L. L. F. (2012). Queijo minas artesanal, tradição centenária: ameaças e desafios. Revista Brasileira de Agropecuária Sustentável, 2(2), 26-34.

European Platform on Life Cycle Assessment. (2002). ELCD Database 2.0. Polystyrene (general purpose) granulate (GPPS), prod. mix. RER. Italy. Retrieved from http://lca.jrc.ec.europa. eu/lcainfohub/datasets/elcd/processes/6ed5e0f8-3914-45339bebc93222bdb2cb_02.01.000.xml

Environmental Protection Agency - EPA (2006). Environmental Protection Agency Life Cicle Assessment: principles and pratice. Ohio: National Risk Management Research Laboratory Cincinnati. $\mathrm{EPA} / 600 / \mathrm{R}-06 / 060$.

Finkbeiner, M., Inaba, A., Tan, R., Christiansen, K. \& Klüppel, H.-J. (2006). The new international standards for life cycle assessment: ISO 14040 and ISO 14044. International Journal of Life Cycle Assessment, 22(2), 80-85. http://dx.doi.org/10.1065/lca2006.02.002

Franklin Associates. (2003). Fuels and energy database for inclusion in the U.S. LCI database. Kansas.

Frischknecht, R., Tuchschmid, M., Faist, E. M., Bauer, C., \& Dones, R. (2007). Strommix und Stromnetz. In R. Dones (Ed.), Sachbilanzen von Energiesystemen: grundlagenfür den ökologischenVergleich von Energiesystemen und den Einbezug von Energiesystemen in Ökobilanzenfür die Schweiz. v2.0. Dübendorf: Paul Scherrer Institut Villigen, Swiss Centre for Life Cycle Inventories. Ecoinvent Report No. 6-XVI. Retrieved from http:www.ecoinvent.org.

Hinz, R. T. P. (2007). Aspectos e impactos ambientais associados ao processo de injeção da blenda PPO/PSAI através do inventário do ciclo de vida (Dissertação de mestrado). Universidade do Estado de Santa Catarina, Joinville.
Hischier, R. (2007). Life cycle inventories of packagings and graphical papers. Dübendorf: Swiss Centre for Life Cycle Inventories. Ecoinvent Report No. 11.

Hofmeister, L. C., Souza, J. A. R., Petrus, J. C. C., \& Laurindo, J. B. (2005). Salga de queijo tipo Minas por impregnação a vácuo. Ciência e Tecnologia de Alimentos, 25(3), 487-494. http://dx.doi.org/10.1590/ S0101-20612005000300016

Hospido, A., Moreira, M. T., \& Feijoo, G. (2003). Simplified life cycle assessment of galician milk production. International Dairy Journal, 13(10), 783-796. http://dx.doi.org/10.1016/S0958-6946(03)00100-6

International Organization for Standardization - ISO. (1998). ISO 14041: environmental management: life cycle assessment: goal and scope definition and life cycle inventory analysis. Geneva.

International Organization for Standardization - ISO. (2000). ISO 14043: environmental management: life cycle assessment: life cycle interpretation. Geneva.

International Organization for Standardization - ISO. (2006a). ISO 14040: environmental management: life cycle assessment: principles and framework. 2nd ed. Geneva.

International Organization for Standardization - ISO. (2006b). ISO 14044: environmental management - life cycle assessment - requirements and guidelines. Geneva.

Kim, D., Thoma, G., Nutter, D., Milani, F., Ulrich, R., \& Norris, G. (2013). Life cycle assessment of cheese and whey production in the USA. Journal of Life Cycle Assessment 18(5), 1019-1035. http:// dx.doi.org/10.1007/s11367-013-0553-9

Machado, E. C., Ferreira, C. L. L. F., Fonseca, L. M., Soares, F. M., \& Pereira Júnior, F. N. (2004). Características físico-químicas e sensoriais do queijo Minas artesanal produzido na região do Serro, Minas Gerais. Ciência e Tecnologia de Alimentos 24(4) 516-521. http://dx.doi.org/10.1590/S0101-20612004000400006

Machado, R. M. G., Freire, V. H., Silva, P. C., Figueiredo, D. V., Ferreira, P. E., \& Nascimento, M. C. P. (2002). Controle Ambiental em Pequenas e Médias Indústrias de Laticínios. Belo Horizonte: Segrac. 224 p.

Maganha, M. F. B. (2006). Guia técnico ambiental da indústria de produtos lácteos. São Paulo: CETESB. 95 p. Série Produção + Limpa. Retrieved from http://www.cetesb.sp.gov.br/tecnologia/producao_ limpa/laticinio.pdf

Nielsen, P., Nielsen, A. M., Weidema, B. P., Dalgaard, R., \& Halberg, N. (2003). LCA food data base. Retrieved from http://www.lcafood. $\mathrm{dk} /$ database

Nogueira, M. C. L., Lubachevsky, G., \& Rankin, S. A. (2005). A study of the volatile composition of Minas cheese. LWT - Food Science and Technology, 38(5), 555-563. http://dx.doi.org/10.1016/j. lwt.2004.07.019

Pre Consultants. (2000). Eco-indicator 99 impact assessment method for LCA. Retrieved from http://www.pre.nl/content/eco-indicator-99.

Programa Semeando. (2011). Identidade mineira. Belo Horizonte. Retrieved from http://www.programasemeando.org.br/Content. aspx ?Code $=1574 \&$ ParentPath $=$ None; $1512 ; 1523 \&$ ContentVersio $\mathrm{n}=\mathrm{C} \&$ ParentCode $=829$

Ribeiro, P. H. (2009). Contribuição ao banco de dados brasileiro para apoio a avaliação do ciclo de vida: fertilizantes nitrogenados (Tese de doutorado). Departamento de Engenharia Química, Escola Politécnica, Universidade de São Paulo, São Paulo.

Siracusa, V., Ingrao, C., Giudice, A. L., Mbohwa, C., \& Rosa, D. M. (2014). Environmental assessment of a multilayer polymer bag for food packaging and preservation: an LCA approach. Food 
Research International 62, 151-161. http://dx.doi.org/10.1016/j. foodres.2014.02.010

United Nations Environment Programme - UNEP, Society of Environmental Toxicology and Chemistry - SETAC. (2013). An analysis of life cycle assessment in packaging for food \& beverage applications. Life Cycle Initiative. Retrieved from http://www. lifecycleinitiative.org
Valt, R. B. G. (2004). Análise do ciclo de vida de embalagens pet, de alumínio e de vidro para refrigerantes no Brasil variando a taxa de reciclagem dos materiais (Dissertação de mestrado). Universidade Federal do Paraná, Curitiba.

Zah, R., \& Hischier, R. (2007). Life Cycle Inventories of Detergents. v2.0. Dübendorf: Swiss Centre for Life Cycle Inventories. Ecoinvent Report No. 12. Retrieved from www.ecoinvent.org 